\title{
Middle Devonian invertebrate trace fossils from the marginal marine carbonates of the Zachełmie tetrapod tracksite, Holy Cross Mountains, Poland
}

\author{
GRZEGORZ NiedŹWIEDZKI, MAREK NARKIEWICZ \& PIOTR SZREK
}

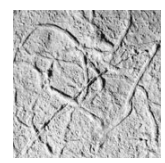

\begin{abstract}
The dolomitic deposits of the Middle Devonian Wojciechowice Formation exposed at the tetrapod tracksite in the Zachełmie Quarry in the Holy Cross Mountains (Poland) are characterised by a low diversity of invertebrate trace fossil association. Four ichnoassemblages can be identified in the track-bearing, lower part of the succession. The most conspicuous are trace fossils produced by arthropods (probably crustaceans), which can form distinctive and large horizontal burrows. The described ichnotaxa (cf. Skolithos isp., cf. Balanoglossites isp., Alcyonidiopsis isp., Spongeliomorpha isp., Gordia isp., and Rhizocorallium isp.) are well known from typical marginal-marine and shallow-marine deposits. Nevertheless, the studied assemblages were found in sparsely distributed horizons and are dominated by a single or a few ichnotaxa with locally high trace-densities. Distribution and composition of the trace fossil assemblages probably reflects occurrence of the impoverished, stressed Cruziana ichnofacies. It was affected by changes in water depth with intermittent periods of subaerial exposure connected with salinity fluctuations. The invertebrate trace fossil assemblage, tetrapod tracks and associated sedimentological features point to deposition in a marginal-marine, mostly peritidal and lagoonal environment with minor terrestrial influences. $\bullet$ Key words: trace fossils, invertebrates, marginal-marine carbonates, Middle Devonian, tetrapod habitats, Central Europe.
\end{abstract}

NiEdŹWIEDZKI, G., NARKIEWICZ, M. \& SZREK, P. 2014. Middle Devonian invertebrate trace fossils from the marginal marine carbonates of the Zachełmie tetrapod tracksite, Holy Cross Mountains, Poland. Bulletin of Geosciences 89(3), 593-606 (9 figures). Czech Geological Survey, Prague. ISSN 1214-1119. Manuscript received June 14, 2013; accepted in revised form January 7, 2014; published online April 2, 2014; issued June 9, 2014.

Grzegorz Niedźwiedzki (corresponding author), Subdepartment of Evolution and Development, Department of Organismal Biology, Uppsala University, Norbyvägen 18A, 75236 Uppsala, Sweden; grzegorz.niedzwiedzki@ebc.uu.se - Marek Narkiewicz \& Piotr Szrek, Polish Geological Institute - National Research Institute, Rakowiecka 4, 00-975 Warszawa,Poland; marek.narkiewicz@pgi.gov.pl,piotr.szrek@pgi.gov.pl

Most ichnological studies of shallow-marine deposits have been based on siliciclastic successions, particularly those comprising alternating sandy and muddy sediments in which abundant, well-preserved invertebrate trace fossils may be common and usually are well visible (MacEachern et al. 2007a, b). By contrast, trace fossils in carbonate strata generally are less distinct and are commonly overlooked thus being difficult to study (Curran \& Martin 2003, Curran 2007, Jaglarz \& Uchman 2010, Buatois \& Mángano 2011). The differences between formations of trace fossils in carbonates versus siliciclastics were summarized by Curran (1994).

The ichnotaxa, ichnoassemblages, and ichnofacies described in this paper occur in shallow marine carbonate deposits with a minor terrestrial input. They belong to the Middle Devonian Wojciechowice Formation of the Holy Cross Mountains, Poland, exposed in the Zachełmie Quarry (Fig. 1) (see Narkiewicz \& Narkiewicz 2010). Unique tetrapod (animals with four legs and digits) footprints and trackways were described from the studied locality, which moved tetrapod origins back to the early Middle Devonian or even earlier times (Niedźwiedzki et al. 2010).

This paper reports for the first time the invertebrate trace fossil assemblages closely associated with tetrapod track-bearing levels. In view of a nearly complete lack of invertebrate body fossils (see Narkiewicz \& Narkiewicz 2010, Niedźwiedzki et al. 2010) the studied material provides important information on invertebrate activity and biodiversity in the early tetrapod habitats. The aim of this paper is to fill the gap in our knowledge with a special focus on the ichnotaxonomic record.

The ichnological investigations were carried out in two sections exposed in the eastern and western part of the Zachełmie Quarry, respectively (Fig. 2). A few specimens of trace fossils were observed on isolated blocks, but their 


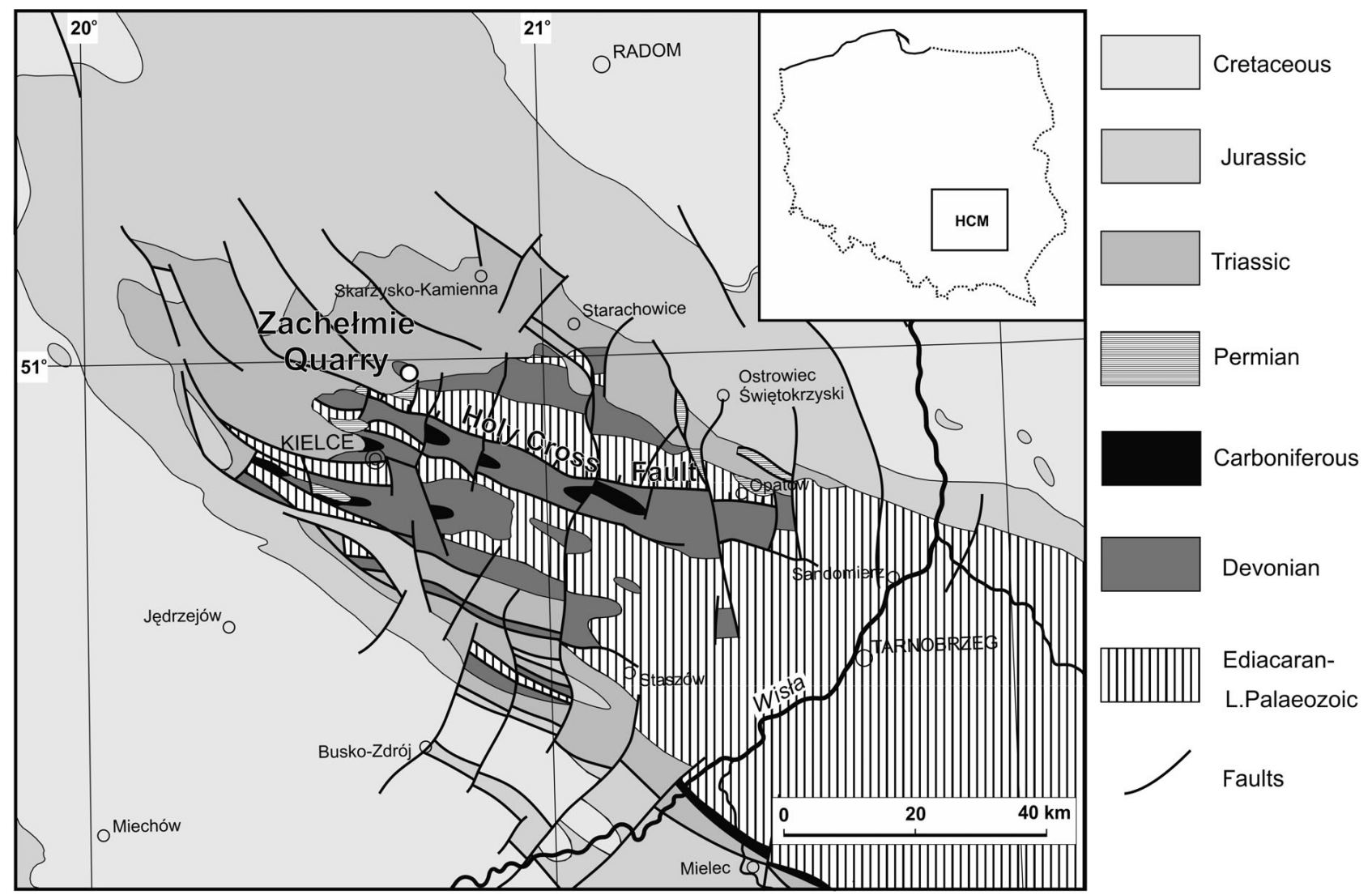

Figure 1. Location of the Zachełmie Quarry in the Holy Cross Mts (HCM) in southern Poland (geological map after Dadlez et al. 2000, simplified).

original position in the section was easy to determine based on lithology, location in the quarry and sedimentological features.

\section{Geological setting}

The abandoned Zachełmie Quarry is situated in the northwestern part of the Holy Cross Mountains, about $10 \mathrm{~km}$ north of the city of Kielce (Fig. 1). The area belongs to the northern part, the so-called Łysogóry Region of the Holy Cross Mountains characterized by distinctive tectonics and palaeogeography (Narkiewicz \& Narkiewicz 2010).

In the Middle to Late Devonian it was located in a belt of pericratonic basins at the southern margin of the Laurussian (Old Red) Continent (Belka \& Narkiewicz 2008). In the Middle Devonian an area of shallow-marine, carbonate-dominated deposition extended over broad regions of central Europe, from Belgium and Germany to Poland, western Ukraine and Moravia. The Polish sector of the basin was surrounded by land areas displaying low topographic relief: elevations of the East European Craton from the north-east, and Sub-Carpathian Arch from the south. The Holy Cross Mountains area was located in the central part of the basin, distant from eroded areas and displaying a continuous marine succession from the latest Early to Late Devonian (Szulczewski 1995).

\section{Sedimentology and facies outline}

The Zachełmie Quarry section exposes a ca $100 \mathrm{~m}$ thick dolomitic succession of Eifelian age (Figs 2, 3A). In its lower half it comprises the Wojciechowice Formation (Fig. 3B) composed of dolomite mudstones to wackestones (dolomicrites) with a variable admixture of terrigeneous clays, quartz silt and sand. They are overlain by crystalline dolomites with amphiporoid biostromes of the Kowala Formation (Figs 3C, 4A), attributed to peritidal to shallow subtidal conditions of a vast carbonate platform (Narkiewicz \& Narkiewicz 2010). The studied strata represent early stages of the transgressive succession that started with the Early Devonian continental to marginal marine clastics and culminated in a development of the late Eifelian and Givetian coral-stromatoporoid carbonate platform and marly deeper-shelf facies.

The tetrapod track-bearing interval is $c a 10 \mathrm{~m}$ thick and occurs in the lowermost part of the succession comprising intercalations of dolomitic marls and marly mudstones, dolomudstones and clayey-dolomitic shales. Common 


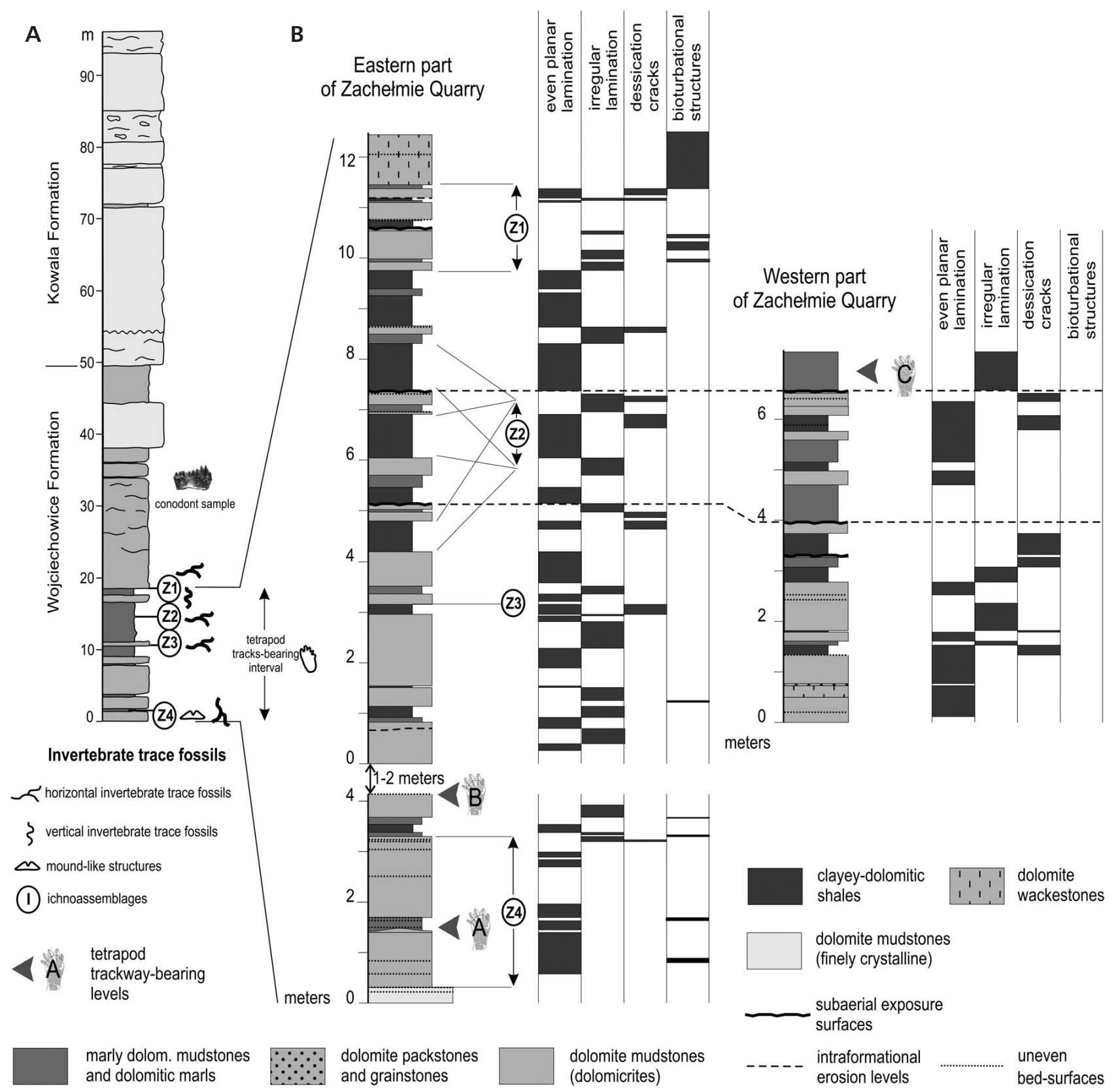

Figure 2. Simplified lithological section of the Zachełmie Quarry (A) with enlarged lower part showing detailed lithology, sedimentary structures, location of tetrapod track-bearing levels and investigated invertebrate trace fossils (B).

lamination is both of regular/planar and wavy to crinkled type, the latter variety attributable to microbial activity. There are several horizons with desiccation cracks, which, together with alleged raindrop impressions, point to extremely shallow-water, intermittently exposed mud-flat environments (Fig. 4B, C). Longer periods of subaerial exposure are indicated by a few paleosol levels (Fig. 4D). Mudcracks, columnar peds, root traces and microbially induced sedimentary structures were observed in association with three distinct pedotypes of very weakly to weakly developed paleosol levels (Narkiewicz \& Retallack 2014, see also Retallack 2011). Macrofossils are rare, including thin-shelled ?bivalves and poorly-preserved plant remains. Ichtyoliths assemblage containing poorly preserved osteichthyan and placoderm fauna was ascertained in grainstone intercalations in the lower part of the profile. They represent an allochthonous material. Evidence of elevated salinity consists of rare dolomite pseudomorphs or casts after sulphates and halite (Fig. 4F). Based on depositional features and taking into account the lack of definitive marine body fossils it may be interpreted that the carbonates of the tetrapod track-bearing horizon have 


\begin{tabular}{|c|c|c|c|}
\hline \multicolumn{2}{|c|}{$\mathrm{A}_{\mathrm{AGE}}$} & \multirow{2}{*}{$\begin{array}{l}\text { CONODONT } \\
\text { ZONES } \\
\text { hermanni }\end{array}$} & \multirow{2}{*}{$\begin{array}{l}\text { NORTHERN } \\
\text { HOLY CROSS MTS } \\
\text { LITHOSTRATIGRAPHY } \\
\begin{array}{l}\text { Nieczulice } \\
\text { Beds Pokrzywianka }\end{array}\end{array}$} \\
\hline \multirow{8}{*}{ 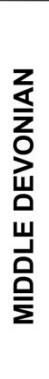 } & \multirow{4}{*}{ 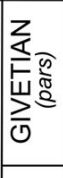 } & & \\
\hline & & varcus middle & Świętomarz Beds \\
\hline & & lower & \multirow{3}{*}{ Skały Beds } \\
\hline & & hemiansatus & \\
\hline & \multirow{4}{*}{ 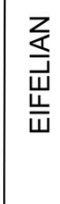 } & $\begin{array}{l}\text { ensensis } \\
\text { kockelianus }\end{array}$ & \\
\hline & & australis & Kowala Fm. (undiv.) \\
\hline & & costatus & Wojciechowice Fm. \\
\hline & & partitus & $\begin{array}{c}\text { Grzegorzowice } \\
\text { Formation }\end{array}$ \\
\hline
\end{tabular}
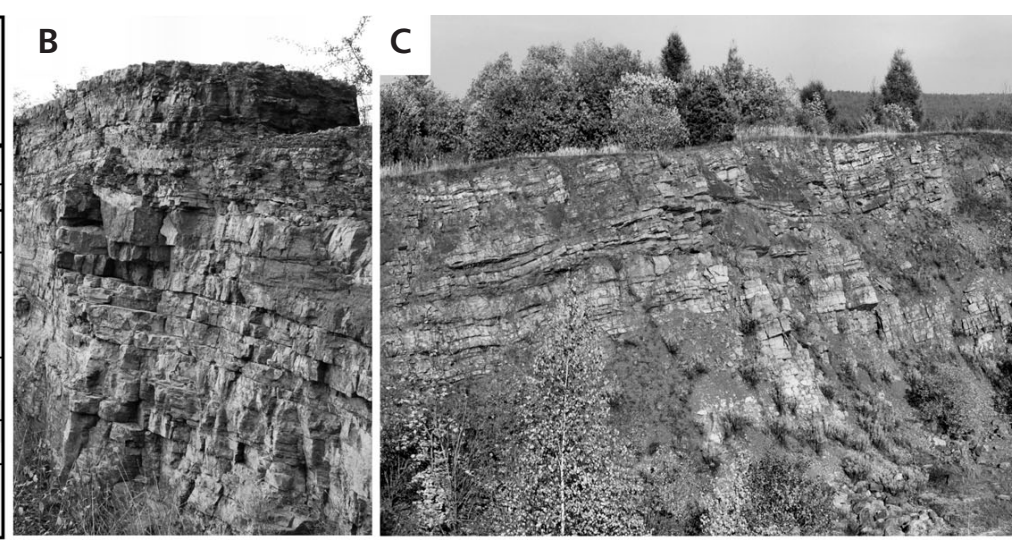

Figure 3. Lithology of the Zachełmie Quarry exposure. A - schematic position of the Zachełmie Quarry section (grey stripe) against the litho- and chronostratigraphic framework of the northern Holy Cross Mountains (after Narkiewicz \& Narkiewicz 2010). • B - lowermost part of the section comprising a succession of grey and reddish, thin- to medium-bedded marly dolomite mudstones, dolomite marls and clayey-dolomitic shales. $\bullet^{\bullet}-$ crystalline dolomites with amphiporoid biostromes of the Kowala Formation.

formed in a marginal marine environment with a minor terrestrial influence, e.g. within and around a coastal lagoon.

The shaly-dolomicritic complex is overlain by $30 \mathrm{~m}$ of medium- and thick-bedded dolomicrites to dolomicrosparites of the uppermost part of the Wojciechowice Formation (Fig. 2A). The dolomites can be classified as mudstones to wackestones, commonly displaying wavy to nodular bedding. Bioturbated beds are common in this part of section, and locally they display clear outlines of dense cylindrical horizontal burrows with a diameter of a few millimetres. Marine body fossils (conodonts and crinoids) appear only ca $20 \mathrm{~m}$ above the strata with tetrapod tracks (Fig. 2A). The conodonts point to the mid-Eifelian costatus Zone and their assemblage is interpreted as a shallow-marine quiet-water biofacies (Narkiewicz \& Narkiewicz 2010, Narkiewicz in press).

The described invertebrate ichnofossils occur in the lowermost part of the section (Fig. 2) in pure to marly-silty dolomites. The pure dolomites occur as internally homogeneous beds, which are $20-50 \mathrm{~cm}$ thick. Vertical (observed as cross-sections or openings of burrows), inclined and horizontal trace fossils were found on lower and sometimes upper surfaces of such beds. In several cases also laminated beds display irregular vertical bioturbational structures referred to activity of invertebrate infauna or poorly preserved plant roots.

\section{The studied material}

Six ichnotaxa plus some other problematic (systematically undeterminable) invertebrate and plant traces were recognised on bedding and parting surfaces in the field and in collected specimens. Two samples were cut in order to obtain polished, differently oriented surfaces. Part of the illustrated material is housed in the collection of the Geological Museum of the Polish Geological Institute - National Research
Institute, Warszawa (collection Muz PGI 1728.II.), while the remaining documentation is based on field observations.

\section{Description of trace fossils}

\section{Vertical structures}

\section{Ichnogenus Skolithos Haldeman, 1840}

\section{cf. Skolithos isp.}

Figure 5A

Material. - A few field observations from the Z1 ichnoassemblage (see Fig. 2).

Description. - Simple, non-branching, straight or gently curved, unlined burrows (shafts) generally oriented perpendicularly or obliquely to bedding planes. They have a more-or-less sharp outline (with distinct borders), cylindrical shape, diameters of $1-3 \mathrm{~mm}$, and are up to $2-3 \mathrm{~cm}$ in length. Circular depressions (negative epirelief) and raised protuberances (positive epirelief) with a diameter of 1 to $3 \mathrm{~mm}$ are visible on the surfaces in the Zachelmie section (Fig. 5A), that could be a preservation variant of the above-described burrows. Vertical burrows occur in a few horizons of well-bedded dolomite mudstones in association with desiccation cracks and microbial wrinkles.

Discussion. - Based on their simple morphology and vertical orientation, these burrows are attributable to the ichnogenus Skolithos. However, their state of preservation and simple morphology does not allow an exact assignment. The ichnogenus Skolithos is a characteristic element of shallow-marine ichnocoenoses (MacEachern et al. 2007a, b), but it may occur in other environments as 

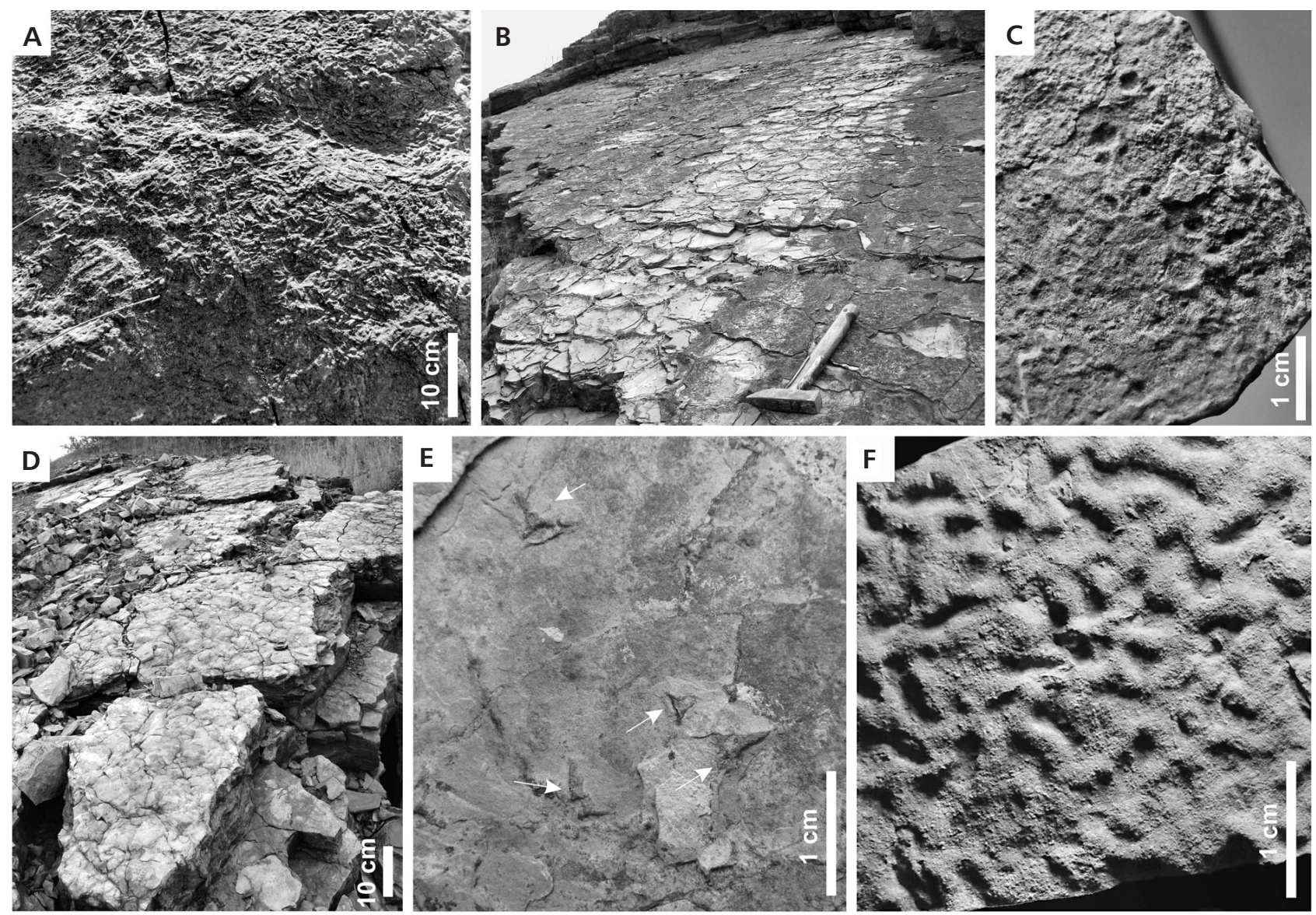

Figure 4. Characteristic sedimentary features of the Zachełmie Quarry section. $\bullet A-$ dolomites with amphiporoids. $\bullet \mathrm{B}$ - part of section with desiccation cracks. $\bullet \mathrm{C}$ - surface with raindrop impressions. $\bullet \mathrm{D}$ - paleosol level. $\bullet \mathrm{E}$ - surface with dolomite pseudomorphs or casts after halite (arrows). $\bullet \mathrm{F}-$ wrinkled surface of a fossilized microbial mat.

well (see Schlirf \& Uchman 2005). Skolithos is a typical dwelling burrow.

\section{Plant root traces}

Figure 5B

Material. - Numerous field observations from the Z1 and Z4 ichnoassemblage (see Fig. 2) and specimen Muz PGI 1728.II.41.

Description. - Simple or branching (dichotomous) irregular, unlined structures (diameters of $0.5-2 \mathrm{~mm}$, and up to $5 \mathrm{~cm}$ in length), straight or curved with the same diameter along the structure (with infill as a host rock) and abundant in places, were identified in a few horizons of well-bedded dolomite mudstones (dolomicrites) in the lower part of section. These structures probably represent plant roots or other plant elements.

Discussion. - Plants may have temporarily colonized emerged areas. In a few places structures similar to plant root traces occur together with desiccation cracks and also layers of supposed paleosols (Narkiewicz \& Retallack 2014). Diverse terrestrial plants (represented by both macro- and microfossils) are documented from continental and marginal marine deposits of the Lower and Middle Devonian, what indicates rapid radiation of the first land forms in different environments (Gensel 2008). The earliest plant roots are described from Lower Devonian deposits (also known from the Holy Cross Mountains - field observations) and are widely distributed in the Middle and Upper Devonian (Davies \& Gibling 2010).

\section{Bedding-plane parallel burrows}

\section{Ichnogenus Balanoglossites Mägdefrau, 1932}

\section{cf. Balanoglossites isp.}

Figure 5D-F

Material. - Numerous field observations from the Z1-Z3 ichnoassemblages (see Fig. 2) and specimens Muz PGI 1728.II.42-43. 
Description. - Bedding-plane parallel burrows lacking a wall, and similar in a general morphology to ichnogenus Thalassinoides, are most common in the upper and middle part of the studied section (Z1-Z3 ichnoassemblages). They are straight to slightly sinuous, with a burrow-fill very similar to the host rock, irregular, simple or branched with constrictions and rare narrower blind branches; have a maximum width of $10-15 \mathrm{~mm}$ and are oval in cross-section or with an elliptical (flattened) cross-section. The burrows are unlined and show rather sharp margins. They were found mainly in two particular horizons (Z2-Z3 ichnoassemblages) on the lower bedding plane surfaces, preserved as natural casts or infills. On a few observed surfaces this trace fossil consists also of short and inclined shafts, which are connected with horizontal tunnels.

Discussion. - The ichnogenus Balanoglossites is a relatively complex trace fossil. It contains mainly U- or Y-shaped tunnels connected by shafts that record both burrowing and boring trace-maker action (Knaust 2008). The constrictions and narrower blind branches of the Zachełmie specimens are the main differences to Thalassinoides isp. The unlined, sharp boundaries of the burrows suggest that they were made in firm sediment (probably microbially stabilized). Kaźmierczak \& Pszczółkowski (1969) suggested that Balanoglossites was produced by annelids and enteropneusts. Patel \& Desai (2009) reported grouped funnel burrows similar to Balanoglossites from recent lagoonal sediments of the intertidal zone.

\section{Alcyonidiopsis Massalongo, 1856}

\section{Alcyonidiopsis isp.}

Figure 5G, H

Material. - A few field observations from the Z2-Z3 ichnoassemblages (see Fig. 2) and specimens Muz PGI 1728.II.44-45.

Description. - Horizontal burrows, straight or gently curved, oval in cross-section, simple, smooth, cylindrical, without a wall, with diameters from 3 to $7 \mathrm{~mm}$. The burrows are either completely filled by granular sediment or certain parts are filled by the overlying dolomite mud. Locally infills are arranged in poorly outlined menisci.

Discussion. - Alcyonidiopsis isp. burrows are very rare in the ichnological record of the Zachełmie Quarry and were found only in two horizons in the middle part of the section (Z2 and Z3 ichnoassemblages). Alcyonidiopsis is a typical pascichnion trace and this burrow has a wide stratigraphic and facies range (Uchman 1999). In some aspects Alcyonidi- opsis is similar to ichnogenus Taenidium Heer, 1877, but, in contrast to the latter, it shows presence of rather rare and indistinct menisci. Poorly preserved Alcyonidiopsis specimens from the Zachełmie Quarry can be confused with Planolites, which is an actively filled burrow (Pemberton \& Frey 1982, Keighley \& Pickerill 1995, Uchman 1995).

\section{Gordia Emmons, 1844}

\section{Gordia isp.}

Figure 5I

Material. - Four field observations from the Z2 ichnoassemblage (see Fig. 2) and specimen Muz PGI 1728.II.46.

Description. - These are long, slightly irregularly bent, smooth and narrow, looping burrows exposed on a bedding-plane. Looped segments are frequently overlapping. The largest specimen is about $150 \mathrm{~mm}$ long (length along the loop) and 2-3 $\mathrm{mm}$ in diameter. Short burrows have smaller diameters, while the longer ones display more regular margins. The burrows are unlined and mostly smooth, although some specimens show an irregular knobby texture in parts of the fill.

Discussion. - Gordia is a facies-breaking form known from marine and non-marine settings (Gaigalas \& Uchman 2004). Looped trails are often left in the Recent by gastropods in small ponds on tidal flats (G.N. - personal observation at St. Audrie's Bay, UK) and also in terrestrial environments (G.N. - personal observations from small ponds at Kampinos National Park, Poland). In typical freshwater environments, especially in ponds and ephemeral puddles, similar traces are interpreted as locomotion trails (repichnia) or feeding traces (pascichnia) (see Gaigalas \& Uchman 2004). Three specimens of Gordia isp. were found in the horizon of well-bedded dolomite mudstones with desiccation cracks and rain drop imprints, which probably represent deposits of a pond-like environment. In non-marine settings Gordialike traces are interpreted as either locomotion traces of various animals (e.g., millipedes, crane fly larvae, pulmonate gastropods) or as feeding traces of insect larvae or gastropods (Gaigalas \& Uchman 2004, Lerner et al. 2007).

\section{Spongeliomorpha Saporta, 1887}

\section{Spongeliomorpha isp.}

Figures 5C, 6A, B

Material. - Specimen Muz PGI 1728.II.47 and numerous field observations from the Z1-Z4 ichnoassemblages (see Fig. 2). 

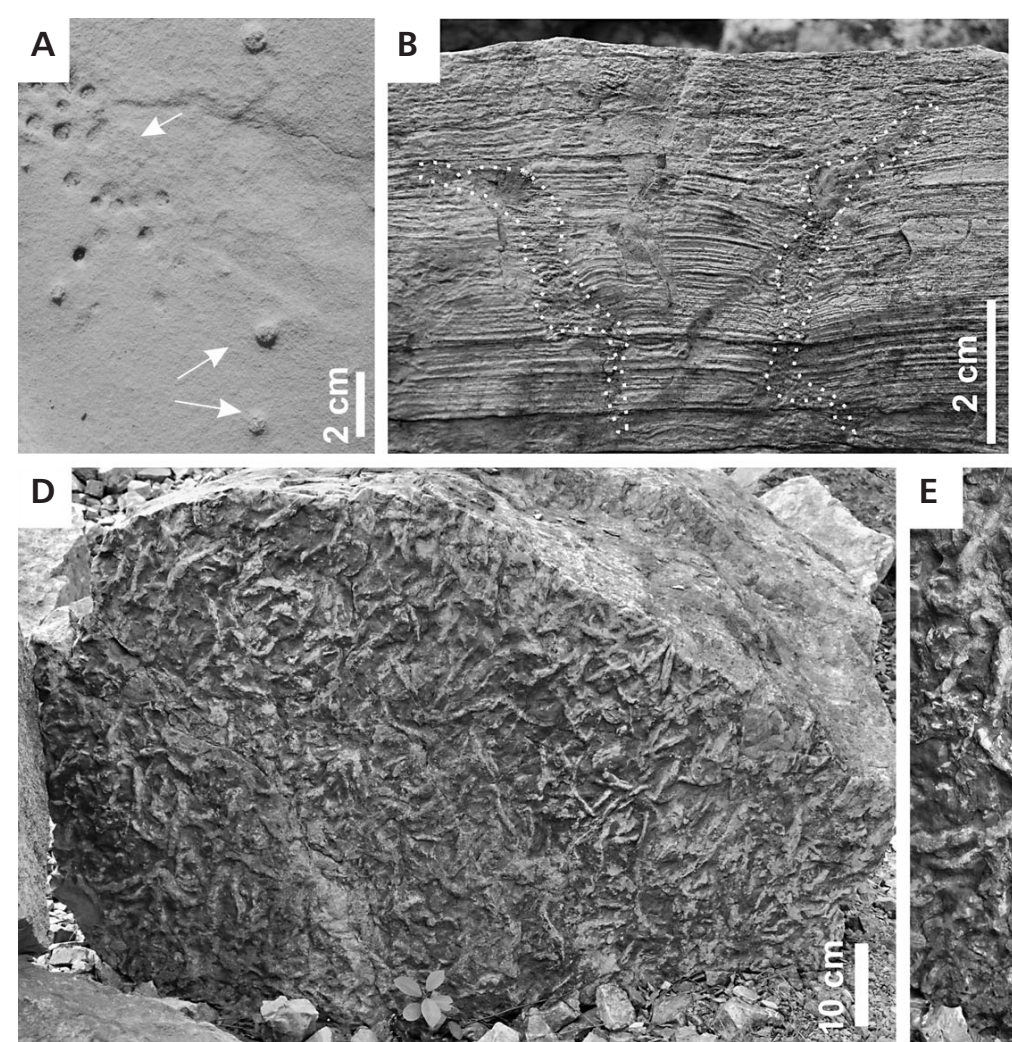
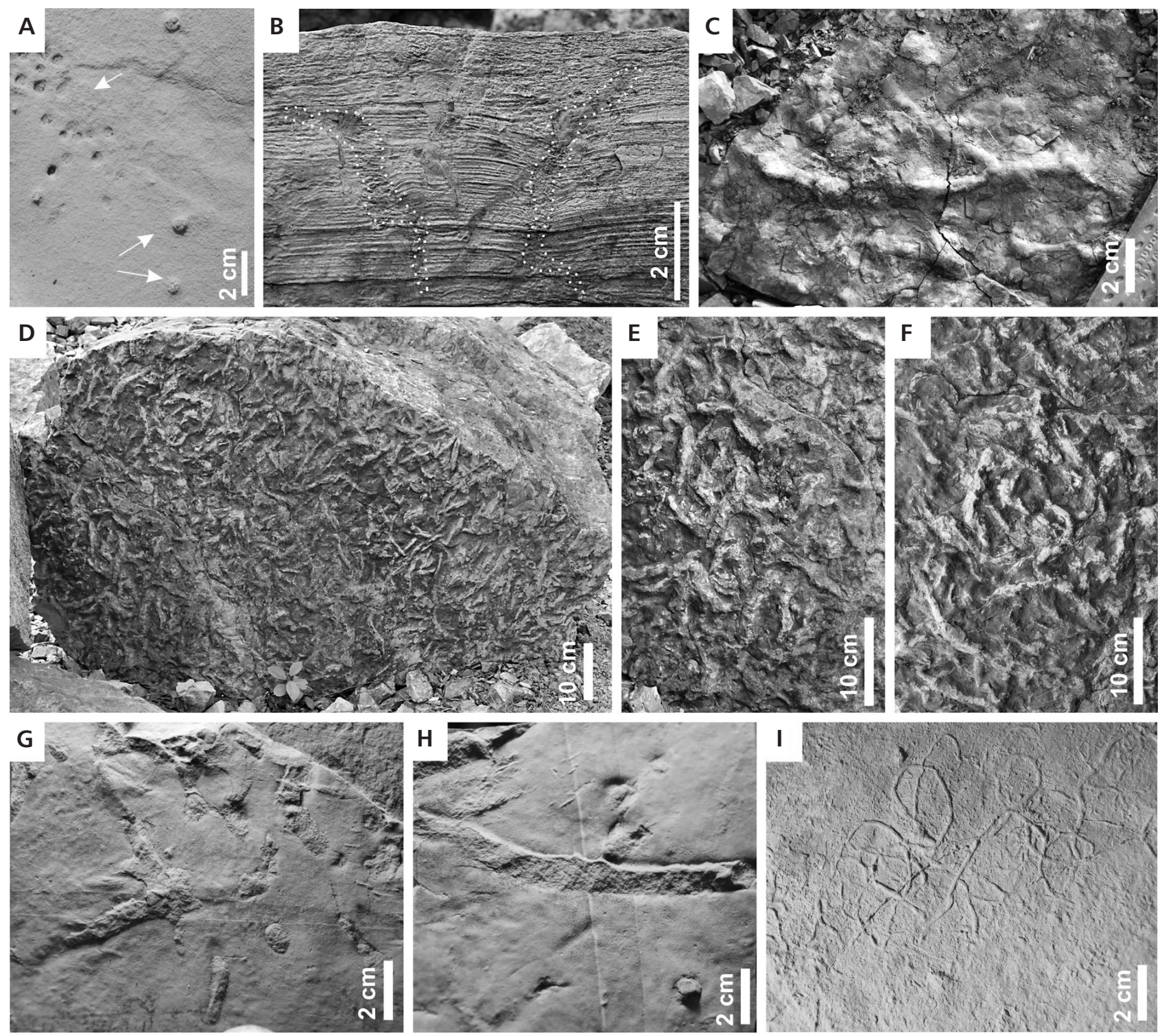

Figure 5. Horizontal and vertical trace fossils (field observations). $\bullet$ A - cf. Skolithos isp. $\bullet$ B - plant root traces. $\bullet$ C - Spongeliomorpha isp. - isolated burrows with Y-shaped branching pattern. $\bullet$ D - surface with numerous traces of cf. Balanoglossites isp. $\bullet$ E, F - magnifications of D. $\bullet$ G, H - Feeding traces Alcyonidiopsis isp. $\bullet \mathrm{I}-$ Gordia isp.

Description. - A few burrows exhibit an Y-shaped branching pattern without noticeably enlarged junctions. Burrows are 5-15 mm wide, cylindrical, without wall. Burrow margins are ornamented with "bulb-like" elements and are similar to structures observed in well-preserved specimens of ichnosubgenus Spongeliomorpha (Ophiomorpha), e.g. the knobby wall-lining burrow of Spongeliomorpha (Ophiomorpha) nodosa (see Schlirf 2005). They are tentatively attributed to the ichnogenus Spongeliomorpha Saporta, 1887 , which is characterized by a typical T- or Y-shaped branching pattern with subordinate sub-vertical and vertical elements (Schlirf 2000, 2005).

Discussion. - Ichnogenus Spongeliomorpha is similar to burrows described as Thalassinoides Ehrenberg, 1944 (see Schlirf 2000, 2005). The two ichnogenera have long been the issue of highly controversial debates among paleoichnologists (see Schlirf 2005). Both traces are usually interpreted as domichnial and fodinichnial structure produced by infaunal crustaceans (e.g., "thalassinidean shrimps") or other kinds of arthropods (Fürsich 1973, Ekdale \& Bromley 2003). Trace makers of these burrows are believed to be obligate or facultative deposit feeders, since many taxa of deposit-feeding crabs, shrimps and lobsters are well known for creating extensive Spongeliomorpha-like burrow systems in modern shallow-marine subtidal to intertidal environments (Curran \& Martin 2003; Curran 2007; MacEachern et al. 2007a, b). Spongeliomorpha occurs in a great 

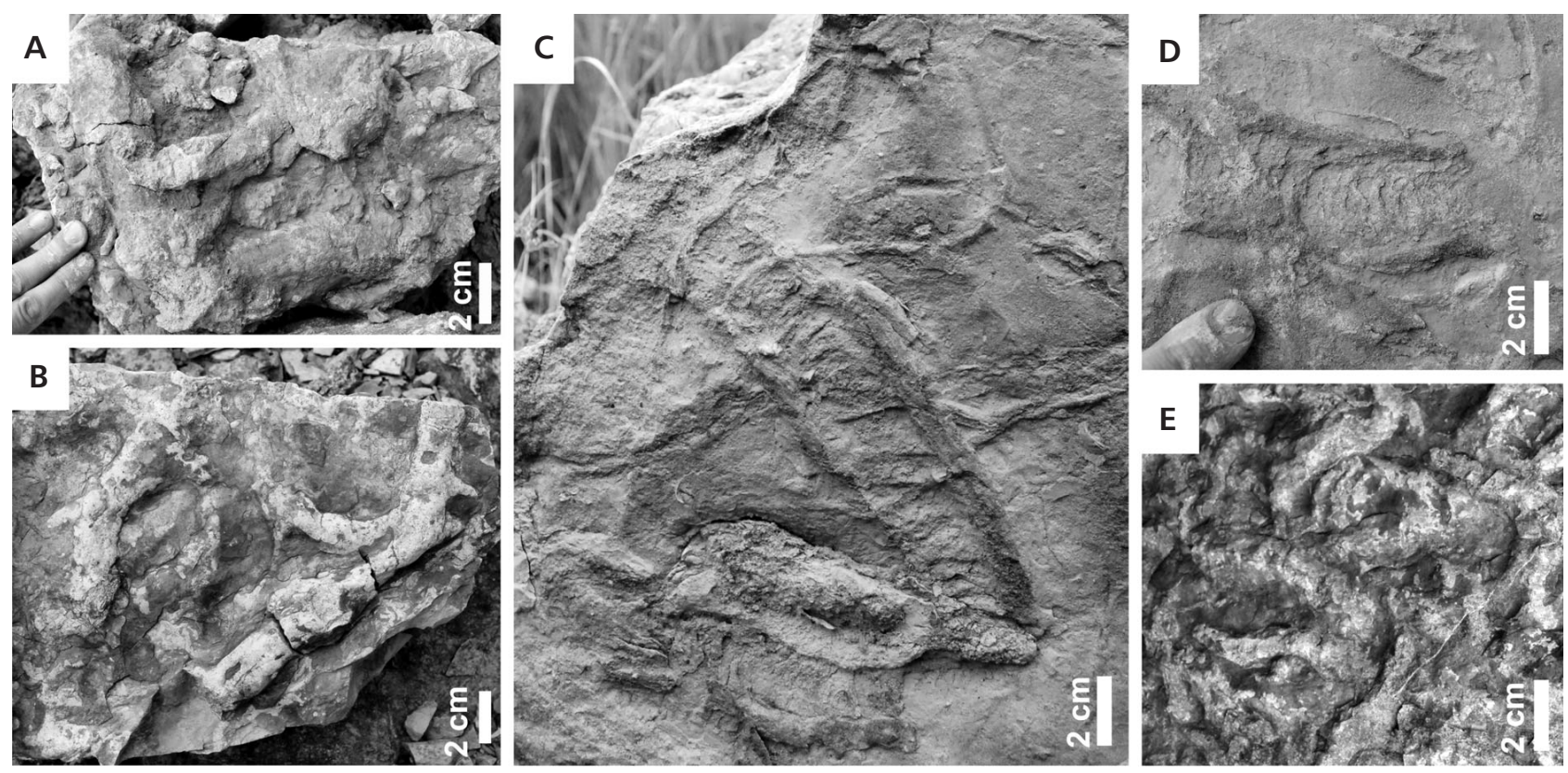

Figure 6. Large burrows (field observations). • A, B - large burrows, Spongeliomorpha isp. • C, D - Rhizocorallium isp., burrows with well visible spreiten structures. $\bullet$ E - numerous cf. Balanoglossites isp. and Rhizocorallium isp.

variety of Phanerozoic marine and also non-marine environments, yet is most typical of the shelf Cruziana ichnofacies (Fürsich 1973; Ekdale 1992; Schlirf 2000, 2005). A few large cylindrical to subcylindrical horizontal burrows showing Y-shaped or multiple branching were also found (Fig. 6A, B). They have a maximum width of $35-40 \mathrm{~mm}$ and are completely filled with the overlying dolomitic mud.

\section{Rhizocorallium Zenker, 1836}

\section{Rhizocorallium isp.}

Figure 6C-E

Material. - A few field observations from the Z3 ichnoassemblage (see Fig. 2).

Description. - The structures tentatively ascribed to this ichnogenus are horizontal or slightly oblique to the bedding plane, composed of a U-shaped marginal tube and spreite encircled by the tube. Limbs of the U-tube are commonly parallel. The size-range is wide, with a maximum observed length of $20 \mathrm{~cm}$, distances between the limbs 40-60 $\mathrm{mm}$ and marginal tube diameters 5-15 $\mathrm{mm}$. The spreite structure is well preserved in a few specimens. $R h i$ zocorallium occurs in the Zachełmie Quarry section only on the lower surfaces of thin- to medium-bedded homogeneous dolomite mudstones.

Discussion. - Rhizocorallium is typical of the Cruziana ichnofacies from the shallow subtidal to intertidal environ- ments (MacEachern et al. 2007a, b; see also Schlirf 2011, Knaust 2013). Recently, a new classification concept for U-shaped spreite structures was proposed by Schlirf (2011). According to this concept U-shaped structures with a single-spreite lamina and with a vertical or inclined orientation should be named Diplocraterion (made by suspensionfeeders). Wedge-shaped structures with double-spreite laminae remain under Rhizocorallium (made by mixed deposit- and suspension feeders), whereas horizontal structures are assigned to Ilmenichnus (made by deposit-feeders).

However, the most recent review of the original descriptions and the analysis of comprehensive new material from the type area of the Rhizocorallium type ichnospecies suggest validity only of Rhizocorallium ichnogenus (Knaust 2013).

\section{Problematic trace fossils and supposed biogenic structure}

Several other trace fossil types are present in the studied section, but are not dealt with herein formally (Figs 7, 8), because either they do not easily conform to existing ichnotaxa or they are poorly preserved or represented only by one or two specimens.

\section{Mound-like structures with openings Figure 7}

Material. - Numerous field observations from the Z4 ichnoassemblage (see Fig. 2). 

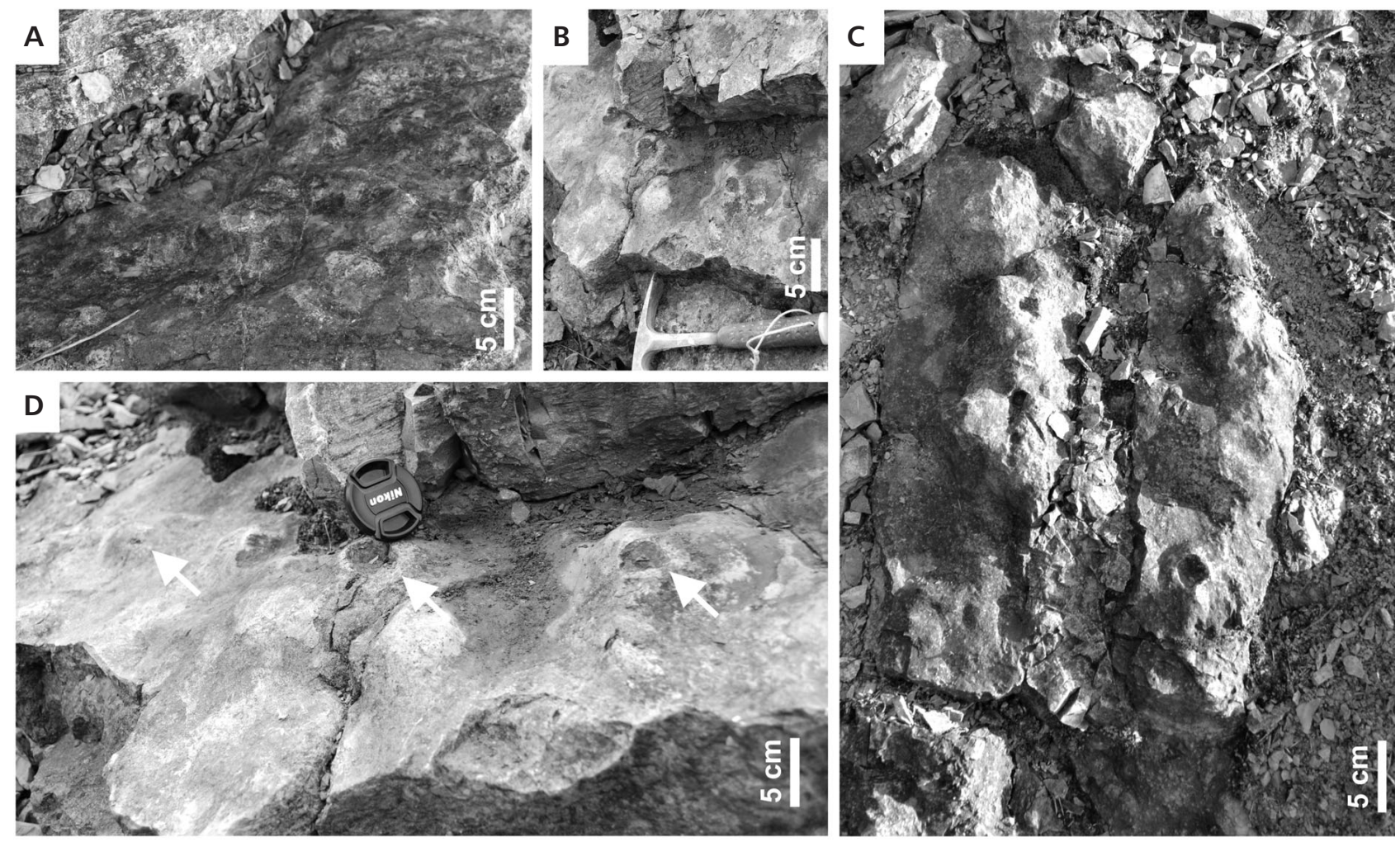

Figure 7. Mounded surface from the lower part of profile which reflects the intense burrowing activity of crustaceans (field observations). $\bullet$ A, B - surfaces with numerous mounds. $\bullet$ C, D - commonly aligned mound-like structures, some with openings on the top (arrows).

Description. - These bedding-plane parallel structures were found on a single surface in the lower part (Z4 ichnoassemblage) of the studied section (Fig. 2). They are preserved as positive structures that may be oval, circular or irregular in shape (in horizontal section), sporadically connected by low, narrow tunnels and forming chains or complexes of closely located structures. The mounds are conical in shape, $2-6 \mathrm{~cm}$ in height, 3-8 cm wide at the base, and 1-5 cm wide near the top. The central part of an individual structure in few cases shows a central burrow of 1-3 cm in diameter. Circular or oval-shaped openings are visible only in apical parts of some mounds.

Discussion. - These structures are similar to present day mud constructions made by crustaceans in lagoons (Curran \& Martin 2003, Curran 2007). These mounds can be compared with the ichnogenus Chomatichnus Donaldson \& Simpson, 1962. The ichnogenus Chomatichnus refers specifically to a cohesive mound of sediment castings, such as those excreted by arenicolid or balanoglossid worms and also structures constructed by crabs (Singh \& Shukla 1991).

\section{Burrows type A}

Figure 8A, B

Material. - A single field observation from the Z3 ichnoassemblage (see Fig. 2).
Description. - The burrow has a length of about $40 \mathrm{~cm}$, width of 2 to $3 \mathrm{~cm}$ and is lacking a wall. This burrow displays passive infill. The burrow margin is unlined and ornamented with deep ridges, which are oblique or transverse to the main axis of the burrow.

Discussion. - In the Zachełmie Quarry section, only one isolated burrow of this type was discovered. The specimen is partly destroyed by erosion and its exact affinity is difficult to determine. The specimen resembles Beaconites, an enigmatic burrow from the Devonian Lower Beacon Formation sediments, Darwin Mountains in Antarctica (Gevers et al. 1971, MacNaughton \& Pickerill 1995), or it is a poorly preserved specimen of Spongeliomorpha carlsbergi (Bromley \& Asgaard, 1979). Beaconites is an ichnogenus comprising a large, segmented burrow which was probably created by a worm-like organism "shovelling" the substrate out of its way. Other explanations suggest that such burrows were probably formed by locomotory back-packing of arthropods or vertebrates (Graham \& Polard 1982). The known records of Spongeliomorpha carlsbergi range from Late Triassic to Miocene and are restricted to continental deposits (Bromley \& Asgaard 1979; Metz 1993a, b, 1996; Gillette et al. 2003; Melchor et al. 2007, 2010). The trace fossil was probably produced by burrowing insects and is regarded as a good indicator of non-marine depositional environments (see Melchor et al. 2010). 


\section{Burrows type B \\ Figure $8 \mathrm{C}-\mathrm{H}$}

Material. - Numerous field observations of the $\mathrm{Z} 1$ and $\mathrm{Z} 3$ ichnoassemblages (see Fig. 2).

Description. - Circular or oval-shaped depressions on top of dolomite bed surfaces are interpreted as burrow entrances. Three such structures were observed ranging from 8 to 15 $\mathrm{cm}$ in maximum width and 5 to $10 \mathrm{~cm}$ in maximum length. The depressions are gently sloped with an average inclination of $5-10^{\circ}$ or are perpendicular to the surface. Parts of the depressions are filled by structurless deposits and those infills protrude above the dolomite bedding-plane.

Discussion. - These large-diameter structures are interpreted as empty (Fig. 8D, E, I) and totally filled entrances (Fig. 8C, F-H). Similar burrows are interpreted as a record of large arthropods (myriapods or large crustaceans) or vertebrates (see Surlyk et al. 2008, Voigt et al. 2011). State of preservation of the specimens does not allow a more detailed examination. However, this is a rare but very interesting trace fossil in the Zachełmie assemblages. Some of these structures are also similar to poorly preserved tetrapod tracks from this locality (Niedźwiedzki et al. 2010) and might be interpreted as undertracks.

\section{Interpretation and discussion}

Generally scarce invertebrate trace fossils occurring in the tetrapod track-bearing interval are associated with particular levels in the lower part of the succession exposed mainly in the eastern part of the Zachełmie Quarry (Fig. 2). Investigated trace fossils show a rather low diversity with a predominance of horizontal burrows attributed to cf. Balanoglossites isp. and Spongeliomorpha isp. The ichnoassemblage is characterized by the dominance of horizontal and inclined trace fossils and subordinate presence of vertical structures of mobile deposit feeders and suspension feeders.

The distribution of invertebrate ichnofossils strongly suggests that there are four characteristic groups (ichnoassemblages Z1 to Z4 - Fig. 2B), which are associated with two sediment-types (clayey-dolomitic shales and dolomitic mudstones) probably deposited in different environmental conditions.

The Z1 assemblage, found in well-bedded dolomite mudstones, comprises mostly cf. Balanoglossites isp., enigmatic burrows of type $\mathrm{A}$ and $\mathrm{B}$, rare vertical burrows (cf. Skolithos isp.) and also plant root traces. This assemblage is associated with a very shallow-water environment characterised by microbial mats with wrinkles typical of small water bodies, and with intermittent subaerial exposure levels with desiccation cracks. The Z2 assemblage comprises trace fossils made by horizontal grazers and feeders (Gordia isp.). It is confined to well-bedded dolomite mudstones with numerous microbial structures and without desiccation cracks, probably related to pond-like environments. The Z3 assemblage includes horizontal burrows (cf. Balanoglossites isp., Spongeliomorpha isp. and rare Rhizocorallium isp.). The Z4 assemblage mainly reflects burrowing activity preserved as mound-like structures and other enigmatic, large, oval-shaped burrows produced by crustaceans or other animals (large Spongeliomorpha isp.). The tetrapod tracks and trackways are associated with the $\mathrm{Z} 1$ and $\mathrm{Z} 2$ ichnoassemblages.

$\mathrm{Z} 2$ and Z3 ichnoassemblages dominated by horizontal burrows are preserved in homogeneous dolomite mudstones and were produced due to feeding activity, probably soon after deposition of a carbonate mud in a stable environment. They seem thus to record a colonization and ensuing foraging by crustacean populations. The Z2 and Z3 assemblages indicate dominance of detritus and deposit feeders in the fauna, which suggests an accumulation of organic detritus in the sediment under rather low-energy conditions.

Available evidence indicates that the studied ichnofauna from Zachełmie shows affinities to the Cruziana ichnofacies. In addition, sedimentological observations suggest that the analysed interval is attributable to the deposits of a shallow marine environment, partly comprising marginal-marine (or even land-water transitional) facies of a very shallow lagoon.

The archetypal Cruziana ichnofacies is characterized by a dominance of horizontal traces of mobile organisms and subordinate presence of vertical and inclined permanent structures, wide variety of ethologic categories, dominance of deposit and detritus feeding traces, and high ichnodiversity and abundance (MacEachern et al. 2007a, b; Buatois \& Mángano 2011). The ichnofacies is characteristic for shallow-water, nearshore marine or coastal environments with unconsolidated cohesive muddy substrates or sandy tempestites and under rather uniform normal salinity.

The Cruziana ichnofacies from the studied succession is characterized by association of horizontal structures which display generally very low diversity and are abundant only locally, in horizons dominated by one or two ichnotaxa (e.g., cf. Balanoglossites isp. and Spongeliomorpha isp.). Such a sporadic distribution of trace fossils with localized high abundance, impoverishment of suspension-feeding trophic types and low diversity suggest environmental conditions departing from normal shallow-marine settings. The ichnofauna from the Zachełmie Quarry may thus represent a rather stressed expression of the Cruziana ichnofacies. Similar interpretation of a comparable shallow-marine ichnorecord was suggested by Mángano et al. (2003) and Jaglarz \& Uchman (2010). 

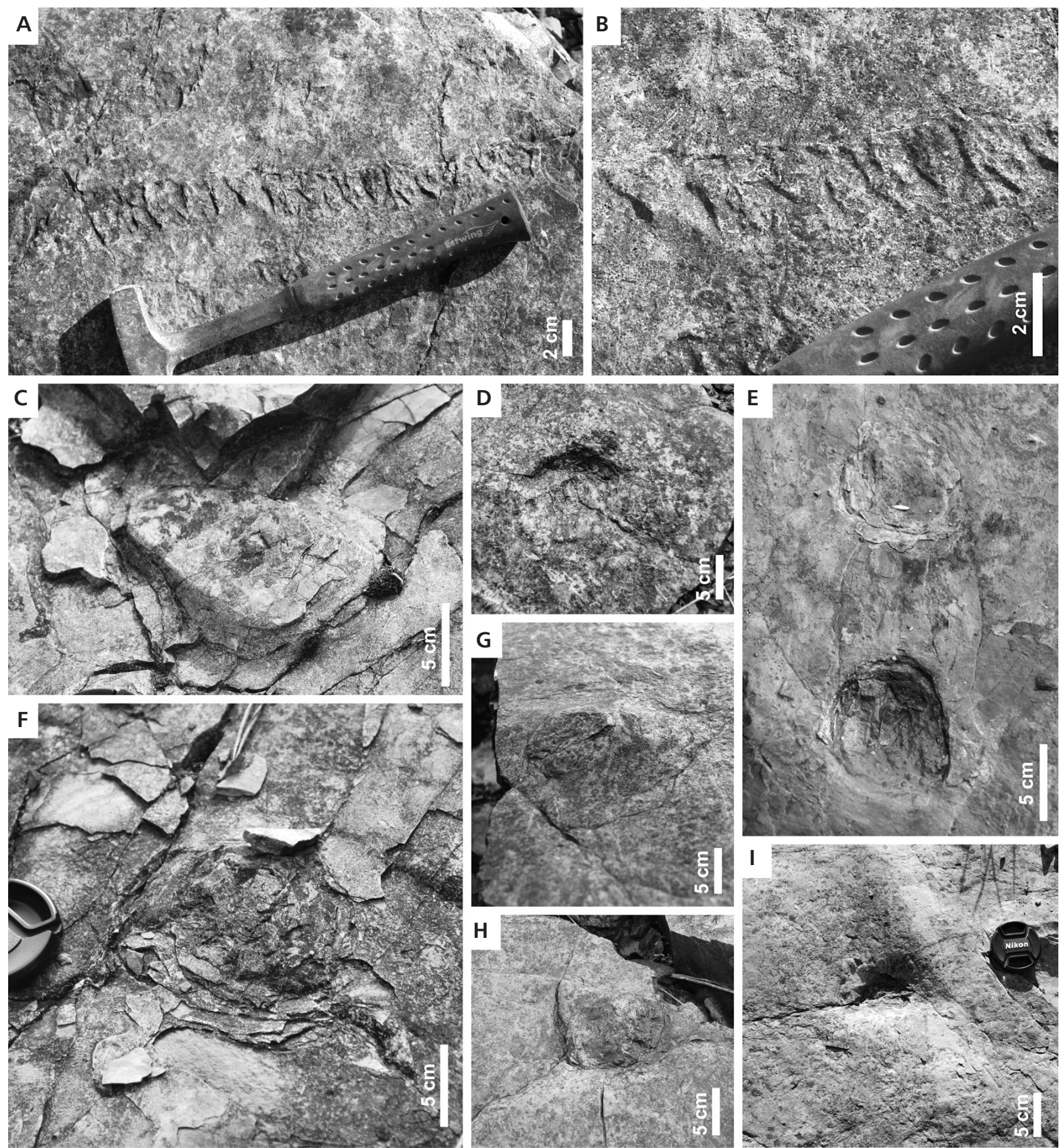

Figure 8. Enigmatic structures and burrows (field observations). $-\mathrm{A}, \mathrm{B}-$ large and long burrow type A similar to the ichnogenus Baeconites. - $\mathrm{C}-\mathrm{I}$ - large burrows type B with empty or totally filled entrances.

The succession from the Zachełmie Quarry contains a sedimentological record of changes in water-depth leading to episodic emersion of the peritidal-lagoonal area. These phenomena could be associated with salinity fluctuations that are among the most important stress factors controlling diversity, distribution, abundance, and type of organisms in marginal-marine settings
(Remane \& Schlieper 1971). Evidence of elevated salinity in the studied section is relatively rare, but nevertheless include characteristic dolomite pseudomorphs or casts after sulphates and halite. It is therefore possible that horizons rich in trace fossils represent low- or normal-salinity episodes, whereas the total absence of trace fossils or bioturbational structures shows evidence of an 


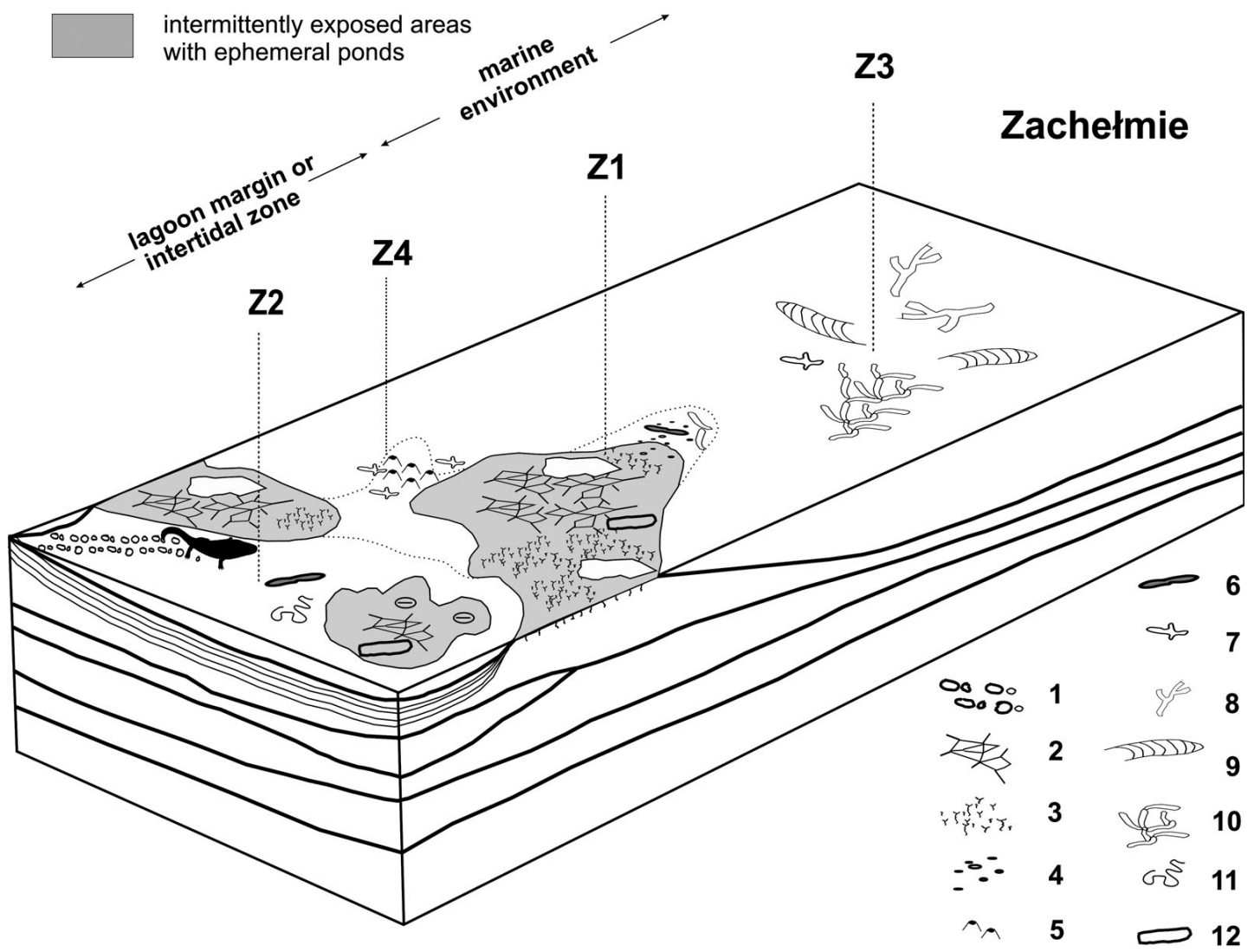

Figure 9. Distribution of trace fossils and ichnoassemblages in depositional environments interpreted for the tetrapod track-bearing sediments from the Zachełmie Quarry. Legend: Ichnoassemblages Z1-Z4 are explained in the text. 1 - tetrapod tracks and trackways; 2 - desiccation cracks; 3 - plant roots; 4 - cf. Skolithos isp.; 5 - mound-like structures; 6 - Alcyonidiopsis isp.; 7 - large burrows Spongeliomorpha isp.; 8 - Spongeliomorpha isp.; 9 - Rhizocorallium isp.; 10 - cf. Balanoglossites isp.; 11 - Gordia isp; 12 - enigmatic burrows type A and B.

increase in salinity up to values above which infauna is eliminated.

The Zachełmie assemblages show analogies to low diversity ichnofauna, dominated by horizontal burrows in shallow-marine carbonate sediments of the Tethyan Middle Triassic (Jaglarz \& Uchman 2010). This characteristic ichnoassemblage, known as the vermicular limestones, points to environmental stress, related foremost to hypersaline conditions. Salinity fluctuations are commonly well visible in the ichnological record (e.g. Buatois et al. 2005, Virtasalo et al. 2006, MacEachern \& Gingras 2007, Buatois \& Mángano 2011) but are rarely described from carbonate facies (Jaglarz \& Uchman 2010).

\section{Conclusions}

The lower, tetrapod track-bearing part of the dolomitic Wojciechowice Formation exposed in the Zachełmie Quarry displays overall rare invertebrate trace fossils including mainly horizontal burrows. The studied assemblages were found in several horizons dominated by a single or a few ichnotaxa with locally high trace-densities, and separated by ichnofossil-barren intervals. The most conspicuous are traces produced by arthropods (probably crustaceans), which can form distinctive and large horizontal burrows.

The investigated ichnofossils may be grouped in four assemblages Z1 to Z4, with dominant cf. Balanoglossites isp. and rare cf. Skolithos isp. in Z1; Gordia isp. in Z2; cf. Balanoglossites isp., Spongeliomorpha isp. and rare Rhizocorallium isp. in Z3; and mound-like and other enigmatic structures in Z4. Tetrapod tracks and trackways are associated with the Z1 and Z2 ichnoassemblages. The composition of the Zachełmie ichnofauna is generally reminiscent of the impoverished Cruziana ichnofacies.

All the described ichnotaxa are well known from, although are not confined to, marginal-marine and shallow-marine successions. Based mostly on sedimentological evidence the ichnoassemblages can be attributed to different marginal-marine subenvironments ranging from lagoon margin or intertidal zone to shallow-subtidal (Fig. 9). Both sedimentological features and the characteristics of the ichnofauna suggest importance of a fluctuating water-depth and, particularly, salinity levels as main environmental controls on the distribution and composition of the trace fossil assemblages. 


\section{Acknowledgments}

This study has been performed within the framework of the project "Controls on tracks development and environmental conditions of earliest tetrapods in the Middle Devonian of the Holy Cross Mts" funded by the Polish Ministry of Science and Higher Education (Grant No. N N307 323439). The authors thank Alfred Uchman (Kraków) and Michael Schlirf (Würzburg) for their helpful comments. The authors are grateful to Daniel Snitting (Uppsala University) for comments on the text and his grammatical improvements of the manuscript. G.N. is currently funded by a Wallenberg Scholarship grant awarded to P.E. Ahlberg (Uppsala University).

\section{References}

BelKa, Z. \& Narkiewicz, M. 2008. Devonian, 383-410. In McCann, T. (ed.) The Geology of Central Europe. Vol. 1: Precambrian and Palaeozoic. Geological Society of London, London.

BRomley, R.G. \& AsgaARd, U. 1979. Triassic freshwater ichnocoenosis from Carlsberg Fjord, East Greenland. Palaeogeography, Palaeoclimatology, Palaeoecology 28, 39-80. DOI 10.1016/0031-0182(79)90112-3

Buatois, L.A., Gingras, M.K., MacEachern, J., Mángano, M.G., Zonneveld, J.-P., Pemberton, S.G., Netto, R.G. \& MARTin, A.J. 2005. Colonization of brackish-water systems through time: Evidence from the trace-fossil record. Palaios 20, 321-347. DOI 10.2110/palo.2004.p04-32

Buatois, L.A. \& Mángano, M.G. 2011. Ichnology: The role of Organism-Substrate Interaction in Space and Time. 358 pp. Cambridge University Press, Cambridge. DOI 10.1017/CBO9780511975622

CuRRAn, H.A. 1994. The palaeobiology of ichnocoenoses in Quaternary, Bahamian-style carbonate environments: The modern to fossil transition, 83-104. In Donovan, S.K. (ed.) Palaeobiology of Trace Fossils. John Wiley and Sons, Chichester.

CuRran, H.A. 2007. Ichnofacies, ichnocoenoses, and ichnofabrics of Quaternary shallow-marine to dunal tropical carbonates: a model and implications, 232-247. In MiLLER III, W. (ed.) Trace Fossils Concepts, Problems, Prospects. Elsevier, Amsterdam.

Curran, H. \& Martin, A.J. 2003. Complex decapod burrows and ecological relationships in modern and Pleistocene intertidal carbonate environments, San Salvador Island, Bahamas. Palaeogeography, Palaeoclimatology, Palaeoecology 192, 229-245. DOI 10.1016/S0031-0182(02)00687-9

Dadlez, R., Marek, S. \& Pokorski, J. 2000. Geological Map of Poland without Cainozoic Deposits (1:1 000 000). Polish Geological Institute, Warszawa.

DAvies, N.S. \& Gibling, M.R. 2010. Cambrian to Devonian evolution of alluvial systems: the sedimentological impact of the earliest land plants. Earth-Science Review 98, 171-200. DOI 10.1016/j.earscirev.2009.11.002

Donaldson, D. \& Simpson, S. 1962. Chomatichnus, a new ichnogenus and other trace fossils from the Wegber Quarry. Liverpool and Manchester Geological Journal 3, 73-81.

DOI 10.1002/gj.3350030106
EKDALE, A.A. 1992. Mudcraking and mudslinging: the joys of deposit-feeding, 145-171. In MAPLES, C.G. \& WeSt, R.R. (eds) Trace fossils. Paleontological Society, Short Courses in Paleontology 5.

Ekdale, A.A. \& Bromley, R.G. 2003. Paleoethologic interpretation of complex Thalassinoides in shallow-marine limestones, Lower Ordovician, southern Sweden. Palaeogeography, Palaeoclimatology, Palaeoecology 192, 221-227.

DOI 10.1016/S0031-0182(02)00686-7

Emmons, E. 1844. The Taconic System based on observations in New York, Massachusetts, Maine, Vermont, and Rhode-Island. 63 pp. Albany, Caroll \& Cook.

FÜRSICH, F.T. 1973. Thalassinoides and the origin of nodular limestones in the Corallian Beds (Upper Jurassic) of southern England. Neues Jahrbuch für Geologie und Paläontologie, Abhandlungen 12, 719-735. DOI 10.1139/e88-085

Gaigalas, A. \& Uchman, A. 2004. Trace fossils from upper Pleistocene varved clays of Kaunas, Lithuania. Geologija 45, 16-26.

Gensel, P.G. 2008. The earliest land plants. Annual Review of Ecology, Evolution and Systematics 39, 459-477.

DOI 10.1146/annurev.ecolsys.39.110707.173526

Gevers, T.W., Frakes, L.A., Edwards, L.N. \& Marzolf, J.E. 1971. Trace fossils in the Lower Beacon Sediments (Devonian), Darwin Mountains, Southern Victoria Land, Antarctica. Journal of Paleontology 45, 81-94.

Graham, J.R. \& Pollard, J.E. 1982. Occurrence of the trace fossil Beaconites antarcticus in the Lower Carboniferous fluviatile rocks of County Mayo, Ireland. Palaeogeography, Palaeoclimatology, Palaeoecology 38, 257-268.

DOI 10.1016/0031-0182(82)90006-2

HaLdEMAN, S.S. 1840. Supplement to number one of "A monograph of the Limniades, and other freshwater bivalve shells of the apparently new animals in different classes, and names and characters of the subgenera in Paludina and Anculosa. 3 pp. J. Dobson, Philadelphia.

HeER, O. 1877. Flora Fossilis Helvetiae. Vorweltliche Flora der Schweiz. 182 pp. J. Wurster \& Company, Zürich.

JAGLARZ, P. \& UCHMAN, A. 2010. A hypersaline ichnoassemblage from the Middle Triassic carbonate ramp of the Tatricum domain in the Tatra Mountains, Southern Poland. Palaeogeography, Palaeoclimatology, Palaeoecology 292, 71-81.

DOI 10.1016/j.palaeo.2010.03.027

KaŹMiercZak, J. \& PszczóŁKowski, A. 1969. Burrows of enteropneusta in Muschelkalk (Middle Triassic) of the Holy Cross Mountains, Poland. Acta Palaeontologica Polonica 14, 299-317.

Keighley, D.G. \& Pickerill, R.K. 1994. The ichnogenus Beaconites and its distinction from Ancorichnus and Taenidium. Palaeontology 37, 305-337.

Knaust, D. 2008. Balanoglossites Mägdefrau 1932 from the Middle Triassic of Germany: Part of a complex trace fossil probably produced by burrowing and boring polychaetes. Paläontologische Zeitschrift 82, 347-372. DOI 10.1007/BF03184427

Lerner, A.J., LuCAS, S.G. \& SpIelman, J.A. 2007. Invertebrate ichnoassemblage from the Triassic Moenkopi Group in north-central Utah, 203-207. In LuCAS, S.G. \& SpIELmann, J.A. (eds) Triassic of the American West. New Mexico Museum of Natural History, Science Bulletin 40. 
MacEachern, J.A., Bann, K.L., Pemberton, S.G. \& Gingras, M.K. 2007a. The ichnofacies paradigm: high-resolution paleoenvironmental interpretation of the rock record, 27-64. In MacEachern, J.A., Bann, K.L., Gingras, M.K. \& PemberTON, S.G. (eds) Applied Ichnology. SEPM (Society for Sedimentary Petrology) Short Course Notes 52.

MacEachern, J.A. \& Gingras, M.K. 2007. Recognition of brackish-water trace-fossil suites in the Cretaceous Western Interior Seaway of Alberta, Canada, 149-193. In Bromley, R.G., Buatois, L.A., Mángano, M.G., Genise, J.F. \& Melchor, R.N. (eds) Sediment-organism interactions: A multifaceted ichnology. Society of Economic Paleontologists and Mineralogists (Society for Sedimentary Geology) Special Publications 88 .

MacEachern, J.A., Pemberton, S.G., Gingras, M.K. \& Bann, K.L. 2007b. The ichnofacies concept: a fifty-year retrospective, 50-75. In Miller III, W. (ed.) Trace Fossils: Concepts, Problems, Prospects. Elsevier, Amsterdam.

MacNaughton, R.B. \& Pickerill, R.K. 1995. Invertebrate ichnology of the nonmarine Lepreau Formation (Triassic), southern New Brunswick, eastern Canada. Journal of Paleontology 69, 160-171.

MägDEFRAU, K. 1932. Über einige Bohrgänge aus dem Unteren Muschelkalk von Jena. Paläontologische Zeitschrift 14, 150-160. DOI 10.1007/BF03041628

Mángano, M.G., Buatois, L.A., Limarino, C.O., Tripaldi, A. \& CAselli, A. 2003. El icnogénero Psammichnites Torell, 1870 en la Formación Hoyada Verde, Carbonífero Superior de la cuenca Calingasta-Uspallata. Ameghiniana 40, 601-608.

Massalongo, A. 1856. Studi Paleontologici. 53 pp. Antonelli, Verona.

NARKIEWICZ, K. 2013. (in press). Taxonomic revision and phylogenetic affinities of the conodont Bipennatus montensis (Weddige 1977) from the Eifelian (Middle Devonian) of Poland. Paläontologische Zeitschrift. DOI 1007/s12542-013-0218-9.

NARKIEwicz, K. \& NARKIEwicz, M. 2010. Mid Devonian carbonate platform development in the Holy Cross Mts. area (central Poland): new constraints from the conodont Bipennatus fauna. Neues Jahrbuch für Geologie und Paläontologie, Abhandlungen 255, 287-300. DOI 10.1127/0077-7749/2009/0025

NARKIEWICZ, M. \& Retallack, G.J. 2014. Dolomitic paleosols in the lagoonal tetrapod track-bearing succession of the Holy Cross Mountains (Middle Devonian, Poland). Sedimentary Geology 29, 74-87. DOI 10.1016/j.sedgeo.2013.10.008.

Niedźwiedzki, G., Szrek, P., NARkiewicz, K., NARkiewicz, M. \& AhlBerg, P.E. 2010. Tetrapod trackways from the early Middle Devonian period of Poland. Nature 463, 43-48. DOI 10.1038/nature08623

PAtel, S.J. \& Desai, B.G. 2009. Animal-sediment relationship of the crustaceans and polychaetes in the intertidal zone around Mandvi Gulf of Kachchh, Western India. Journal of Geological Society of India 74, 233-259. DOI 10.1007/s12594-009-0125-6

Pemberton, S.G. \& Frey, R. 1982. Trace fossil nomenclature and the Planolites-Palaeophycus dilemma. Journal of Paleontology $56,843-881$.

Pemberton, S.G., Spila, M., Pulham, A.J., Saunders, T., Maceachern, J.A., Robbins, D. \& Sinclair, I.K. 2001. Ichnology and sedimentology of shallow to marginal marine systems: Ben Nevis and Avalon Reservoirs, Jeanne d'Arc Basin. Geological Association of Canada, St. John's Newfoundland, Short Course Notes 15, 1-353.

Remane, A. \& Schlieper, C. 1971. Biology of Brackish Water. 372 pp. John Wiley and Sons, New York.

Retallack, G.J. 2011. Woodland hypothesis for Devonian tetrapod evolution. Journal of Geology 119, 235-258. DOI $10.1086 / 661255$

SAPORTA, G.D. 1887. Nouveaux documents relatifs aux organismes problématiques des anciennes mers. Bulletin de la Société Géologique du France, 3me Série 15, 286-302.

SCHLIRF, M. 2000. Upper Jurassic trace fossils from the Boulonnais (northern France). Geologia et Palaeontologia 34, 145-213.

SCHLIRF, M. 2011. A new classification concept for U-shaped spreite trace fossils. Neues Jahrbuch für Geologie und Paläontologie, Abhandlungen 260, 33-54. DOI 10.1127/0077-7749/2011/0127

SCHLIRF, M. \& UCHMAN, A. 2005. Revision of the ichnogenus Sabellarifex Richter, 1921 and its relationship to Skolithos Haldeman, 1840 and Polykladichnus Fürsich, 1981. Journal of Systematic Palaeontology 3, 115-131. DOI 10.1017/S1477201905001550

SeILACher, A. 2007. Trace Fossil Analysis. 226 pp. Springer Verlag, Berlin, Heidelberg, New York.

Singh, I.B. \& ShuKLA, U.K. 1991. Significance of trace fossils in the Bhuj Sandstone (Lower Cretaceous), Bhuj area, Kachchh. Journal of the Palaeontological Society of India 36, 121-126.

SuRlyk, F., Milàn, J. \& NoE-NygaARD, N. 2008. Dinosaur tracks and possible lungfish aestivation burrows in a shallowcoastal lake; lowermost Cretaceous, Bornholm, Denmark. Palaeogeography, Palaeoclimatology, Palaeoecology 231, 253-264. DOI 10.1016/j.palaeo.2008.07.004

Szulczewski, M. 1995. Depositional evolution of the Holy Cross Mts. (Poland) in the Devonian and Carboniferous - a review. Geological Quarterly 39, 471-488.

Uchman, A. 1995. Taxonomy and palaeoecology of flysch trace fossils: the Marnoso-arenacea Formation and associated facies (Miocene, northern Apennines, Italy). Beringeria 15, 1-115.

UCHMAN, A. 1999. Ichnology of the Rhenodanubian Flysch (Lower Cretaceous-Eocene) in Austria and Germany. Beringeria 25, 65-171.

Virtasalo, J.J., Kotilainen, A.T. \& Gingras, M.K. 2006. Trace fossils as indicators of environmental change in Holocene sediments of the Archipelago Sea, northern Baltic Sea. Palaeogeography, Palaeoclimatology, Palaeoecology 240, 453-467. DOI 10.1016/j.palaeo.2006.02.010

Voigt, S., Scheneider, J.W., SAber, H., Hminna, A., Lagnaoui, A., Klein, H., Brosig, A. \& Fischer, J. 2011. Complex tetrapod burrows from Middle Triassic red beds of the Argana Basin (Western High Atlas, Morocco). Palaios 26, 555-566. DOI 10.2110/palo.2011.p11-014r 